\title{
SEARCHING FOR PALINDROMIC SEQUENCES IN PRIMARY STRUCTURE OF PROTEINS
}

\author{
MARCIN HOFFMANN ${ }^{1}$ AND JACEK RYCHLEWSKI ${ }^{1,2}$

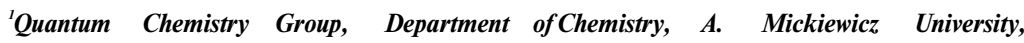 \\ ul. Grunwaldzka 6, 60-780 Poznań, Poland \\ ${ }^{2}$ Poznań Networking and Supercomputing Center, Institute ofBioorganic Chemistry, \\ ul. Wieniawskiego 17, 61-713 Poznań, Poland
}

\begin{abstract}
Protein data base SWISSPROT was tested in the search for palindrome sequences in primary structure of polypeptides. The obtained results indicate that palindrome words are present in protein structure and there is a number of them. Half of the length of the longest palindrome was 76 and in accordance with expectations the shorter the length of the palindrome the greater number of them has been determined.
\end{abstract}

\section{INTRODUCTION}

Palindrome is a word or phrase which reads the same backwards as forwards, for example radar [1], Palindromic sequences among nucleic acids are well known and of utmost importance [2-6]. Restriction endonucleases, discovered in late sixties, usually recognize palindromic sequences of DNA and after the recognition they cleave the DNA [1]. Restriction enzymes which recognize specific sequences of DNA are widely exploited in laboratories for gene isolation and cloning, genetic recombination, examining of chromosome structure, and sequencing of long DNA fragments [1,7-10]. Some nuclear receptors recognize as their target palindromic sequences of DNA [11-16]. For example the nuclear glucocorticoid receptor recognizes a palindromic fragment of human DNA $[17,18]$. Moreover palindromic sequences are present in telomeres and are necessary for initiation of DNA replication therein $[19,20]$,

All in all palindromic sequences of DNA were studied in depth and their role is quite well understood [1-20]. On the other hand the presence of palindromic sequences in primary structure of proteins has not gained as much attention $[21,22]$. Therefore an attempt to search for palindromic sequences in polypeptides have been undertaken.

\section{METHODS}

Protein database, SWISSPROT [23], was chosen to be examined during the search for palindromic sequences. A computer program which was searching for palindromic words was written based on an algorithm:

1. read in the sequence of the protein and the length of the polypeptide chain,

2. choose the initial values of the length of a half of palindrome LH (largest value, equaled 99) and the length of a gap in the middle of palindrome LG (initially 0),

3. start from the first aminoacid,

4. check whether a sequence of the length of $2 * L H+L G$ is a palindrome with the gap in the middle of the length $\mathrm{LG}$ 
- if yes write the name of the protein and the position of the beginning and the end of a palindrome, move to next step (number 5),

- if no move to next step (number 5),

5. move the starting position of one aminoacid and repeat 4 until the end of polypeptide chain is reached,

6. increment by one LG and go to step 3 (until LG is lower than 6),

7. decrement by one LH and go to step 3 (until LH is greater than 2),

8. after checking one protein sequence check the next protein.

\section{RESULTS}

The number of observed palindromes in sequence of proteins and half of the length of these palindromes are presented in Table I. The Chart 1 presents the number of palindromes in logarithmic scale versus their half-lengths.

Table I. Number of observed palindromes and half of their length

\begin{tabular}{|c|c|c|c|c|c|c|c|c|}
\hline $\begin{array}{l}\text { Half-length } \\
\text { of } \\
\text { palindrome } \\
\text { (1) }\end{array}$ & $\begin{array}{r}\mathbf{N} \\
\text { observed } \\
\text { total } \\
(2) \\
\end{array}$ & $\begin{array}{l}\text { of } \\
\text { alindromes } \\
\text { exclusive } \\
\text { (3) }\end{array}$ & $\begin{array}{c}\text { Half-length } \\
\text { of } \\
\text { palindrome } \\
\text { (1) }\end{array}$ & \multicolumn{2}{|c|}{$\begin{array}{c}\text { No. of } \\
\text { observed palindromes }\end{array}$} & $\begin{array}{l}\text { Half-length } \\
\text { of } \\
\text { palindrome } \\
\text { (1) }\end{array}$ & \multicolumn{2}{|c|}{ 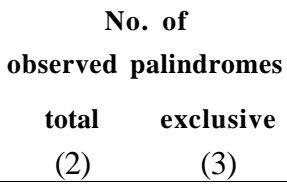 } \\
\hline 77 & 0 & 0 & 52 & 113 & 5 & 27 & 1047 & 94 \\
\hline 76 & 1 & 1 & 51 & 119 & 6 & 26 & 1148 & 101 \\
\hline 75 & 3 & 2 & 50 & 126 & 7 & 25 & 1255 & 107 \\
\hline 74 & 7 & 4 & 49 & 134 & 8 & 24 & 1374 & 119 \\
\hline 73 & 13 & 6 & 48 & 143 & 9 & 23 & 1507 & 133 \\
\hline 72 & 18 & 5 & 47 & 152 & 9 & 22 & 1661 & 154 \\
\hline 71 & 23 & 5 & 46 & 161 & 9 & 21 & 1841 & 180 \\
\hline 70 & 28 & 5 & 45 & 172 & 11 & 20 & 2043 & 202 \\
\hline 69 & 32 & 4 & 44 & 185 & 13 & 19 & 2268 & 225 \\
\hline 68 & 36 & 4 & 43 & 201 & 16 & 18 & 2526 & 258 \\
\hline 67 & 40 & 4 & 42 & 222 & 21 & 17 & 2817 & 291 \\
\hline 66 & 44 & 4 & 41 & 250 & 28 & 16 & 3147 & 330 \\
\hline 65 & 48 & 4 & 40 & 281 & 31 & 15 & 3549 & 402 \\
\hline 64 & 52 & 4 & 39 & 315 & 34 & 14 & 4028 & 479 \\
\hline 63 & 56 & 4 & 38 & 352 & 37 & 13 & 4632 & 604 \\
\hline 62 & 62 & 6 & 37 & 392 & 40 & 12 & 5371 & 739 \\
\hline 61 & 70 & 8 & 36 & 433 & 41 & 11 & 6323 & 952 \\
\hline 60 & 76 & 6 & 35 & 479 & 46 & 10 & 7560 & 1237 \\
\hline 59 & 82 & 6 & 34 & 528 & 49 & 9 & 9300 & 1740 \\
\hline 58 & 86 & 4 & 33 & 586 & 58 & 8 & 11839 & 2539 \\
\hline 57 & 92 & 6 & 32 & 648 & 62 & 7 & 15882 & 4043 \\
\hline 56 & 96 & 4 & 31 & 717 & 69 & 6 & 22430 & 6548 \\
\hline 55 & 100 & 4 & 30 & 792 & 75 & 5 & 35235 & 12805 \\
\hline 54 & 104 & 4 & 29 & 868 & 76 & 4 & 65853 & 30618 \\
\hline 53 & 108 & 4 & 28 & 953 & 85 & 3 & 202558 & 136705 \\
\hline
\end{tabular}

Number of observed palindromes exclusive - the palindromes of the greater length are not counted 


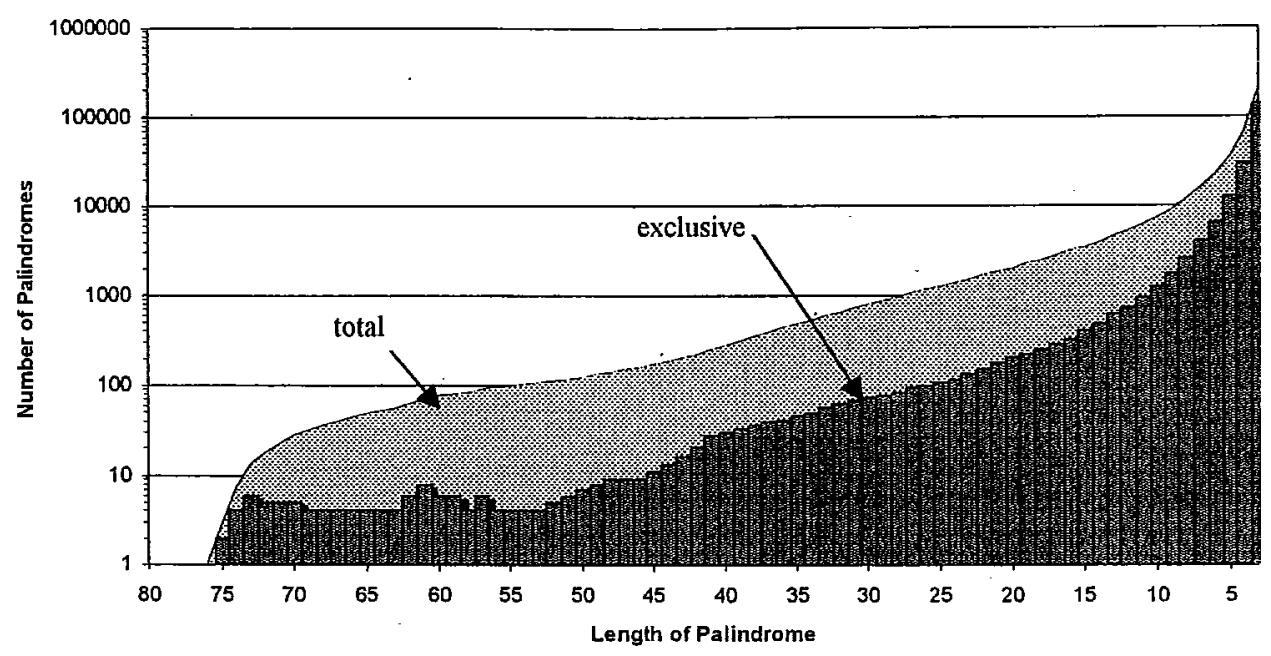

Chart 1. Number of observed palindromes and half of their length

As can be easily noticed the longest observed palindrome has the length of $2 * 76=152$ aminoacids, whereas as expected the number of observed palindromes increases as the length of palindrome decreases. Number of palindromes of the length $2 * 3=6$ is 202558 if counting all hits and 136705 if longer palindromes are excluded.

\section{DISCUSSION AND CONCLUSIONS}

The obtained results indicate that in primary structure of polypeptides one can observe palindromic sequences of various length. As could be expected the shorter the palindrome the more frequently it occur. The longest palindrome sequences are monotonous - they are build from one or two aminoacids. The role of palindromes for structure or function of the protein remains still unclear and definitely deserves further examination. Whether their presence is caused by accident or these palindromic sequences are underlying some structural or functional features is currently under investigation and further results are to be published soon. All in all palindromic words of aminoacids do exist in the sequence of proteins and examining of their role would be an exciting challenge.

\section{Acknowledgement}

Authors thank Prof. J. Barciszewski for fruitful discussions and for stimulating interest in finding palindromic sequences in protein primary structure. The support from Poznań Networking and Supercomputing Center is gratefully acknowledged.

\section{References}

[1] L. Styer, Biochemistry, 4th Ed., W. H. Freeman \& Co: New York (1995).

[2] C. Chauveau, C. Decourt, M. Cogne, Gene 222, 279 (1998).

[3] M. Gupta, R. Zak, T. A. Libermann, M. P. Gupta, Molec. Cell. Biol. 18, 7243 (1998). 
[4] S. Shankar, B. Mohapatra, A. Suri, Biochem. Biophys. Res. Comm. 243, 561 (1998).

[5] D. G. Taghian, H. Hough, J. A. Nickoloff, Genetics 148, 1257 (1998).

[6] S. R. Bhaumik, K. V. R. Chary, G. Govil, K. L. Liu, H. T. Miles, Nucleic Acids Res. 26, 2981 (1998).

[7] Y. G. Kim, J. Smith, M. Durgesha, S. Chandrasegaran, Biol. Chem. 379, 489 (1998).

[8] L. Kittler, A. Bell, B. C. Baguley, G. Lober, Biol. Chem. 379, 519 (1998).

[9] A. Sander, M. Ruess, S. Bereswill, M. Schuppler, B. Steinbrueckner, J. Clin. Microbiol. 36, 2973 (1998).

[10] E. Urbach, C. Schindler, S. J. Giovannoni, FEMS Microbiol. Letts. 162, 111 (1998).

[11] S. N. Ponnampalam, S. Elsen, C. E. Bauer, J. Biol. Chem. 273, 30757 (1998).

[12] R. Duan, W. Porter, S. Safe, Endocrinology 139, 1981 (1998).

[13] V. Martin, S. Ribieras, M. C. Rio, R. Dante, Biol. Chem. 379, 409 (1998).

[14] K. Mori, N. Ogawa, T. Kawahara, H. Yanagi, T. Yura, J. Biol. Chem. 273, 9912 (1998).

[15] C. S. Song, M. H. Jung, S. C. Kim, T. Hassan, A. K. Roy, B. Chatterjee, J. Biol. Chem. 273, 21856 (1998).

[16] M. Detapia, V. Metzler, M. Mougel, B. Ehresmann, C. Ehresmann, Biochem. 37, 6077 (1998).

[17] D. Pearce, W. Matsui, J. N. Miner, K. R. Yamamoto, J. Biol. Chem. 273, 30081 (1998).

[18] J. Lechner, T. Welte, W. Doppler, Immunobiol. 198, 112 (1998).

[19] K. Willwand, E. Mumtsidu, G. Kuntzsimon, J. Rommelaere, J. Biol. Chem. 273, 1165 (1998).

[20] C. H. Huang, Y. S. Lin, Y. L. Yang, S. W. Huang, C. W. Chen, Molec. Microbiol. 28, 905 (1998).

[21] M. Royo, M. A. Contreras, E. Giralt, F. Albericio, M. Pons, J. Am. Chem. Soc.120, 6639 (1998).

[22] E. Ardini, G. Pesole, E. Tagliabue, A. Magnifico, V. Castronovo, M. E. Sobel, M. I. Colnaghi, S. Menard, Molec. Biol. Evolut. 15, 1017 (1998). 